\title{
PENINGKATAN PEMAHAMAN MATERI BANGUN DATAR DENGAN MENGGUNAKAN MEDIA KERTAS ORIGAMI PADA SISWA KELAS VI MI DATOK SULAIMAN PUTRA
}

\author{
Mawarni \\ Institut Agama Islam Negeri Palopo \\ Jl. Agatis Balandai Kota Palopo, Sulawesi Selatan \\ E-mail: mawarni.kulsum@gmail.com
}

\begin{abstract}
This research discusses the improvement of students' understanding of mathematics, especially flat-up material. To find out whether the application of origami paper media in class VI MI Datok Sulaiman can improve students' understanding. This research is classroom action research (CAR) which consists of two cycles, each cycle carried out as much as 2 meetings, with stages of Planning, Implementation, Observation, and Reflection. The results showed that: by applying origami paper media can improve the material understanding of students 'flat wake, Based on the test of student learning outcomes in the sixth grade of MI Datok Sulaiman Putra Palopo which was conducted in two cycles showed that students' learning outcomes increased, from the first cycle the average score the mean is 76 with a percentage of completeness of $71 \%$ while the second cycle has an average value of 87 with a percentage of $96 \%$ and has met the KKM value of 70
\end{abstract}

Keywords: Build Flat, Media, Origami.

\begin{abstract}
Abstrak
Penelitian ini membahas tentang peningkatan pemahaman siswa pada pelajaran matematika khususnya materi bangun datar. Tujuan penelitian ini adalah: untuk mengetahui apakah penerapan media kertas origami pada kelas VI MI Datok Sulaiman dapat meningkatkan pemahaman siswa. Penelitian ini merupakan penelitian tindakan kelas (PTK) yang terdiri dari dua siklus, masing-masing siklus dilaksanakan sebanyak 2 kali pertemuan, dengan tahapan Perencanaan, Pelaksanaan, Observasi, dan Refleksi. Hasil penelitian menunjukkan bahwa: dengan diterapkan media kertas origami dapat meningkatkan pemahaman materi bangun datar siswa, Berdasarkan tes hasil belajar siswa di kelas VI MI Datok Sulaiman Putra Palopo yang dilakukan sebanyak dua siklus menunjukkan bahwa hasil belajar peserta didik mengalami peningkatan, dari siklus I nilai rata-ratanya 76 dengan persentase ketuntasan $71 \%$ sedangkan siklus II nilai rata-ratanya 87 dengan persentase 96\% dan sudah memenuhi nilai KKM yaitu 70.
\end{abstract}

Kata Kunci: Bangun Datar, Media, Origami.

\section{PENDAHULUAN}

Pengetahuan matematika sebagai ilmu dasar yang senantiasa berkembang pesat baik dari aspek materi maupun kegunaannya sesuai dengan tuntutan perkembangan zaman. Oleh karena itu, tuntutan tersebut mendorong manusia untuk mampu mengkreasikan pembelajaran dan 


\section{6 | Mawarni}

mengembangkannya dalam penerapan matematika sebagai ilmu dasar tersebut. Telah diketahui bersama bahwa pembelajaran matematika sangat penting pada setiap jenjang pendidikan maka perlu mendapatkan perhatian yang serius. Masalah yang sering dihadapi anak didik dalam pembelajaran matematika ialah ketidakmampuan untuk mengeksplorasikan apa yang diketahui kepada orang lain. Menurut Astri kurang pahamnya siswa terhadap konsep dasar matematika malas untuk belajar matematika (Astri Nur Wulandari, 2018:12).

Untuk lebih mudah dalam menyampaikan pembelajaran matematika telah diperkenalkan beragam metode, model maupun strategi dalam pembelajaran yang dapat dijadikan rujukan dan digunakan dalam pembelajaran. Agar mampu mencapai tujuan pembelajaran, guru dituntut untuk mampu memahami konsep dan proses pembelajaran dalam berbagai aktivitas (Rustan, Hanifah, \& Kanro, 2018). Metode pembelajaran merupakan cara yang digunakan oleh tenaga pendidik yang merupakan subjek dari proses pembelajaran untuk menyampaikan bahan pelajaran kepada peserta didik guna mencapai hasil yang telah diinginkan. Memilih metode yang diterapkan dalam proses belajar mengajar harus disesuaikan dengan rumusan tujuan pembelajaran (Syamsu S, 2017 : 23) Strategi pembelajaran yang digunakan oleh guru sebaiknya membuat siswa dapat berpartisipasi dalam pembelajaran yang telah direncanakan sehingga pembelajaran dapat berjalan sesuai dengan tujuan.

Selain metode dan strategi pembelajaran acapakali pendidik menggunakan media pembelajaran untuk mempermudah guru dalam menyampaikan materi kepada peserta didik agar pembelajaran lebih efektif. Media adalah bentuk jamak dari medium yang berasal dari bahasa Latin yang secara harfiah berarti "Perantara" atau "Penyalur". Hal ini bermaksud bahwa media merupakan wahana penyalur informasi belajar atau penyalur pesan (Rostina Sundayana, 2013 : 4). Rusman berpendapat bahwa media merupakan sarana yang digunakan oleh sumber pesan atau penggunanya dalam menyampaikan pesan kepada sasaran atau penerima pesan tersebut (Rusman, 2011 : 15). Selain itu para ahli juga mendefinisikan media sebagai sesuatu yang bersifat menyalurkan pesan dan dapat merangsan pikiran, perasaan, dan kemauan audien sehingga dapat memfasilitasi penggunanya dalam proses belajar yang terjadi pada dirinya (Asnawir, 2002 : 14). Berdasarkan pengertian tersebut, dapat dikatakan media sebagai alat bantu yang digunakan seseorang dalam menyampaikan pesan kepada penerima pesan.

PiJIES: Pedagogik Journal of Islamic Elementary School 
Media adalah alat dalam berkomunikasi baik cetak maupun audio visual serta peralatannya. Media yang digunakan seharusnya dirancang agar dapat dilihat, di dengar dan dibaca. Melihat berbagai batasan-batasan pada media, terdapat persamaan diantara batasan tersebut yaitu bahwa media adalah semua yang dapat digunakan pengirim pesan untuk disalurkan kepada penerima pesan sehingga dapat merangsang kemampuan berfikir, pengelolaan perasaan, fokus dan keinginan serta perhatian siswa sedemikian rupa sehingga proses belajar terjadi (Arif Sadiman, 2012:7). Dari pengertian media tersebut dapat disimpulkan bahwa media merupakan alat yang digunakan untuk menyalurkan informasi kepada penerima pesan. Dalam memilih media terdapat beberapa hal yang harus diperhatikan, antara lain, sasaran pembelajaran, penggunaan yang tepat, keadaan siswa/mahasiswa, perangkat-perangkat yang tersedia baik perangkat keras maupun perangkat lunak, kualitas teknis dan biaya.

Salah satu media yang dapat dijadikan sebagai rujukan dalam menyampaikan informasi kepada penerima informasi dalam konteks pembelajaran adalah Media origami. Seni origami atau melipat kertas merupakan tradisi yang berasal dari Jepang yang dimulai dari bentuk yang paling sederhana, dan dari lipatan tersebut mendapatkan bentuk yang menarik. Origami berupa kertas warna-warni yang berukuran 5 sampai 9 inci kuadrat (Liya Susanti dan abdul, $2012: 2$ ).

Adapun fungsi penggunaan media origami ini ialah untuk meingkatkan pemahaman materi bangun datar. Syafruddin mendefenisikan pemahaman sebagai kemampuan untuk menterjemahkan, menginterpretasi, mengekstrapolasi dan menghubungkan antara fakta atau konsep (Syafruddin Nurdin, 2002: 105). Sedangkan menurut Sardiman dalam Islaqhuddin mendefinisikan pemahaman sebagai menguasai sesuatu dengan pikiran, yang berarti harus mengerti secara makna, maksud dan implikasinya serta aplikasinya, sehingga menyebabkan siswa dapat memahami suatu situasi. (Islaqhuddin Baharsyah, 2012 : 6). Adapun indikator pemahaman matematika menurut Vivi Utari, Dkk., menyatakan bahwa pemahaman konsep ialah menyatakan ulang sebuah konsep, mengklasifikasikan objek menurut sifat-sifat tertentu (Vivi Utari, 2014: 34).

Penggunaan media pada penelitian ini diterapkan pada materi bangun datar. Materi bangun datar adalah salah satu materi yang akan diajarkan pada jenjang sekolah dasar. Di kelas VI semester I bangun datar difokuskan pada pembahasan menentukan luas daerah dan keliling bangun datar. Secara umum materi geometri ini akan diteruskan pembahasannya ditingkat SMP maupun SMA. Oleh karena itu, pembahasan ditingkat SD akan menjadi dasar dan pondasi bagi siswa terutama pada bab geometri dapat dimulai pada 


\section{8 | Mawarni}

penanaman konsep yang benar tentang geometri itu sendiri. Bangun datar ialah bangun yang dibuat pada permukaan datar, contohnya bagun bersisi empat disebut bangun datar karena seluruh bangun terletak dalam bidang yang datar. (ST. Nugroho dan B. Harahap, 2005:20). Ada macam-macam bangun datar diantaranya bangun segitiga, persegi, segi panjang, belah ketupat, jajar genjang, layang-layang dan trapesium. Pada pembelajaran matematika di SD khususnya kelas 6 materi tentang bangun datar dibatasi dengan materi bangun datar segibanyak. Tujuan dari penelitian ini dilakukan adalah untuk mengetahui apakah penerapan media kertas origami pada kelas dapat meningkatkan pemahaman siswa.

\section{METODE}

Penelitian ini termasuk penelitian tindakan kelas (PTK) dengan jenis data kualitatif dan kuantitatif. Subjek dalam penelitian ini adalah seluruh siswa kelas VI MI Datok Sulaiman Putra Kota Palopo yang berjumlah 32 siswa yang terdiri 16 laki-laki dan 16 perempuan. Adapun tehnik pengumpulan data menggunakan tes, Observasi dan dokumentasi. Rumus yang digunakan untuk mencari hasil dari mean data tunggal yang seluruh skornya berfrekuensi satu adalah sebagai berikut : $\mathrm{M}_{\mathrm{x}}=\frac{\sum X}{N} \mathrm{M}_{\mathrm{x}}=$ Mean yang dicari, $\Sigma X=$ Jumlah seluruh nilai siswa, dan $\mathrm{N}=$ Jumlah siswa. (Untuk memperoleh frekuensi relatife (angka persen) dengan rumusan sebagai berikut: $P_{N}^{F} \times 100 \% \mathrm{~F}=$ Frekuensi yang sedang dicari persentasenya, $\mathrm{N}=$ Number of Cases ( jumlah frekuensi/banyak individu),P = angka Persentase (Anas Sudijono 2010 : 81). Penelitian ini dilakukan 2 siklus, setiap siklusnya terdiri dari 2 kali pertemuan dengan tahap perencanaan, pelaksanaan, observasi, dan refleksi.

Indikator keberhasilan dari penelitian tindakan kelas ini adalah sebagai berikut : Terjadi peningkatan persentase aktivitas guru yang dilihat selama proses pembelajaran berlangsung melalui peningkatan rata - rata persentase setiap aspek yang diamati seperti yang tercantum dalam indikator pada lembar aktivitas guru. Terjadi peningkatan persentase aktivitas belajar siswa yang dilihat selama proses pembelajaran berlangsung melalui peningkatan rata - rata persentase setiap aspek yang diamati seperti yang tercantum didalam indikator pada lembar aktivitas siswa. Untuk hasil tes, kriteria keberhasilan yang digunakan adalah mengacu pada peningkatan nilai rata-rata pemahaman siswa pada materi bangun datar antara siklus I dan siklus II. Apabila terjadi peningkatan nilai rata-rata pemahaman siswa baik secara angka maupun kategori, maka penerapan media kertas origami berhasil meningkatkan pemahaman materi bangun datar.

PiJIES: Pedagogik Journal of Islamic Elementary School 


\section{HASIL PENELITIAN}

1. Peningkatan aktivitas guru pada kelas VI MI Datok Sulaiman

Deskripsi Hasil analisis observasi aktivitas guru pada siklus I, Membuka pelajaran 25\%, menggali pengetahuan awal siswa 18,75\%, member motivasi yang dapat membangkitkan minat siswa 18,75\%, menyampaikan tujuan pembelajaran $18,75 \%$, menjelaskan sub konsep 18,75\%, menggunakan media yang bervariasi 25\%, media yang digunakan sesuai dengan materi 18,75\%, membimbing siswa dalam kegiatan pengamatan 18,75\%, membimbing siswa dalam kegiatan diskusi $18,75 \%$, mengoptimalkan interaksi antar siswa dengan guru $18,75 \%$, media yang digunakan dapat mengaktifkan siswa $18,75 \%$, member kesempatan kepada siswa untuk bertanya $18,75 \%$.

Adapun hasil analisis observasi aktivitas guru pada siklus II, Membuka pelajaran $25 \%$, menggali pengetahuan awal siswa $18,75 \%$, member motivasi yang dapat membangkitkan minat siswa $25 \%$, menyampaikan tujuan pembelajaran $18,75 \%$, menjelaskan sub konsep 18,75\%, menggunakan media yang bervariasi 25\%, media yang digunakan sesuai dengan materi $18,75 \%$, membimbing siswa dalam kegiatan pengamatan 18,75\%, membimbing siswa dalam kegiatan diskusi 18,75\%, mengoptimalkan interaksi antar siswa dengan guru $18,75 \%$, media yang digunakan dapat mengaktifkan siswa $18,75 \%$, memberi kesempatan kepada siswa untuk bertanya $25 \%$.

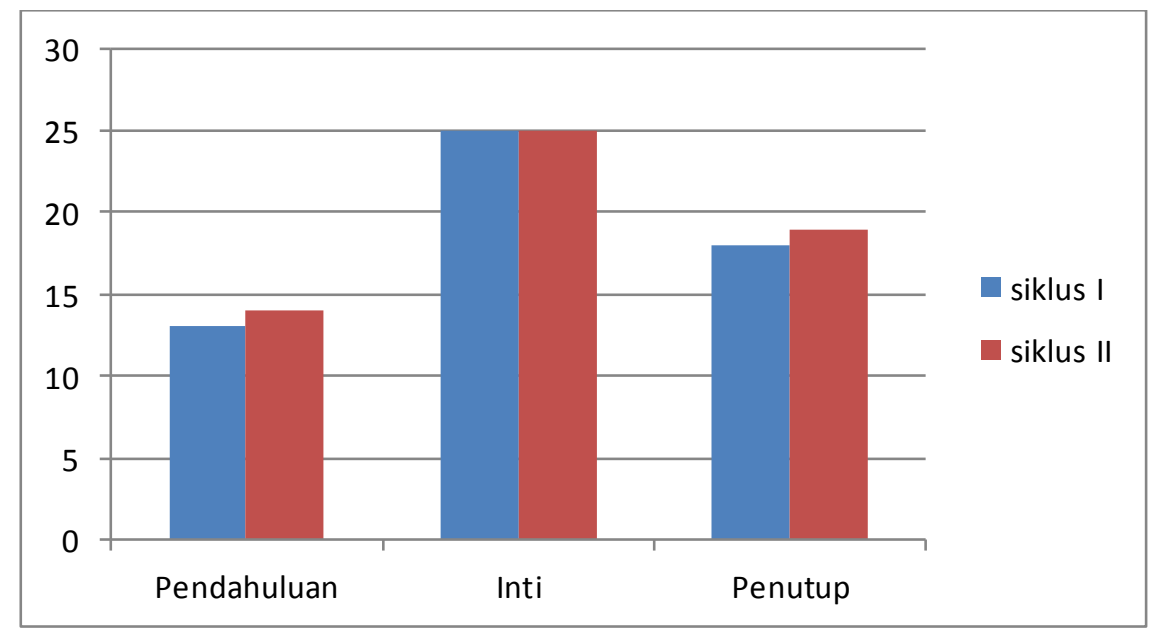

Diagram 1. Peningkatan Aktifitas Guru siklus I dan II 


\section{0 | Mawarni}

2. Peningkatan aktivitas siswa pada kelas VI MI Datok Sulaiman

Deskripsi aktivitas siswa pada siklus I diperoleh bahwa dari 32 siswa kelas VI MI Datok Sulaiman Putra setelah diterapkan media kertas Origami pada siklus I, siswa yang masuk kelas tepat waktu $25 \%$, Siswa yang menyiapakan perlengkapan belajar $21,87 \%$, Siswa yang tidak melakukan kegiatan lain yang akan mengganggu pelajaran $12,5 \%$, siswa yang aktif mengajukan pendapat $15,62 \%$, siswa yang aktif melaksanakan kegiatan pembelajaran 18,75\%, siswa yang memperlihatkan hasil kerja kepada guru $18,75 \%$, siswa yang mengerjakan soalsoal secara mandiri $12,5 \%$, siswa yang menanyakan hal-hal yang belum dipahami $18,75 \%$, mengerjakan soal latihan yang diberikan $15,63 \%$, siswa yang mengacungkan tangan untuk maju menjawab soal latihan dipapan tulis 15,63\%, siswa yang aktif member tanggapan atas jawaban yang dikerjakan oleh temannya $15,63 \%$.

Deskripsi aktivitas siswa pada siklus II diperoleh bahwa dari 32 siswa kelas VI MI Datok Sulaiman Putra setelah diterapkan Kertas Origami Pada siklus II, siswa yang masuk kelas tepat waktu 25\%, Siswa yang menyiapakan perlengkapan belajar 25\%, Siswa yang tidak melakukan kegiatan lain yang akan mengganggu pelajaran $21,87 \%$, siswa yang aktif mengajukan pendapat $21 \%$, siswa yang aktif melaksanakan kegiatan pembelajaran 25\%, siswa yang memperlihatkan hasil kerja kepada guru 21,87\%, siswa yang mengerjakan soal-soal secara mandiri 21,87\%, siswa yang menanyakan hal-hal yang belum dipahami $25 \%$, mengerjakan soal latihan yang diberikan 21,87\%, siswa yang mengacungkan tangan untuk maju menjawab soal latihan dipapan tulis $17,14 \%$, siswa yang aktif member tanggapan atas jawaban yang dikerjakan oleh temannya $25 \%$.

PiJIES: Pedagogik Journal of Islamic Elementary School 


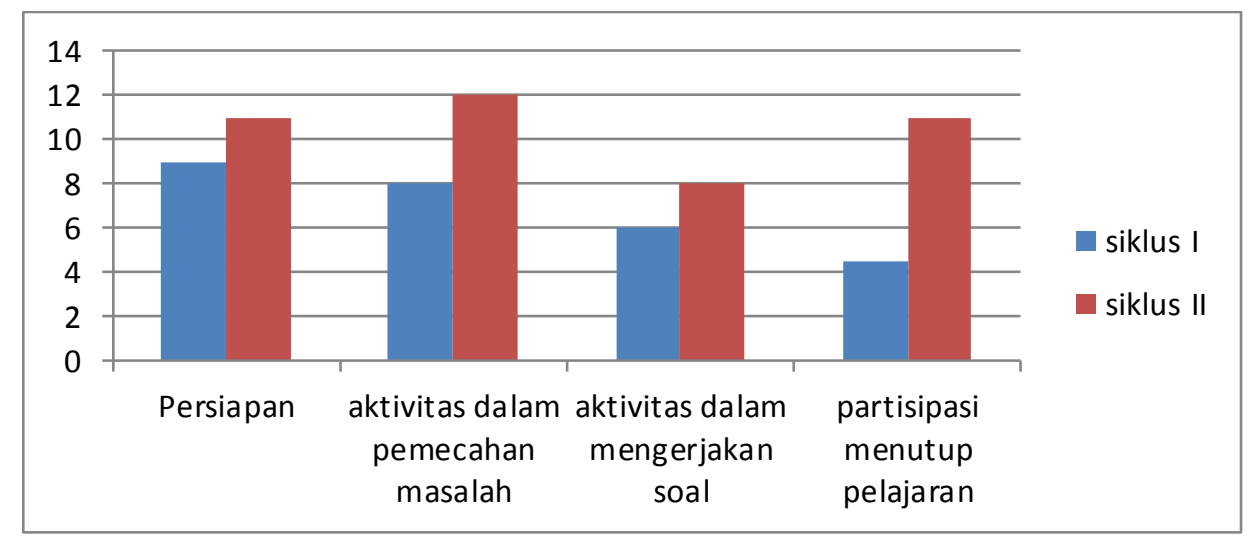

Diagram 2 Hasil Peningkatan Aktifitas Siswa Siklus I dan II

3. Peningkatan pemahaman materi bangun datar pada kelas VI MI Datok Sulaiman

Deskripsi Prasiklus, Bab pendahuluan telah dijelaskan bahwa pembelajaran matematika sudah berjalan dengan baik, dalam pembelajaran, guru menerapkan metode yang bervariasi terkadang kelompok terkadang pula ceramah tergantung topik yang dijelaskan. Namun, ketika diberikan tes pratindakan hasil tes tersebut tergolong rendah, hal tersebut dikarenakan kurangnya pemahaman siswa terhadap materi yang diberikan. Berdasarkan tabel hasil evaluasi prasiklus sehingga diperoleh data nilai rata-rata hasil belajar peserta didik kelas VI MI Datok Sulaiman Putra Palopo diperoleh dengan rumus rata-rata: $\frac{2125}{32}=66$, jadi nilai ratarata siswa dengan menggunakan media kertas origami dalam pelajaran matematika diatas menunjukkan bahwa hasil yang diperoleh tidak memenuhi KKM. diketahui bahwa 32 siswa yang mengikuti tes pada prasiklus ternyata 4 atau $11 \%$ siswa yang mendapat kategori sangat baik, 3 atau 9\% peserta didik mendapat nilai termasuk kategori baik, 15 atau 45\% siswa mendapat nilai termasuk kategori cukup, 16 atau 43\% siswa mendapat nilai termasuk kategori kurang.

Deskripsi siklus I diperoleh nilai rata-rata hasil belajar peserta didik kelas VI MI Datok Sulaiman Putra Palopo diperoleh dengan rumus rata-rata: $\frac{2435}{32}=76$, jadi nilai rata-rata siswa dengan menggunakan media kertas origami dalam pelajaran Matematika menunjukkan bahwa dari 32 siswa yang mengikuti tes evaluasi pada siklus I siswa yang mendapat nilai $\geq 75$ sebanyak 23 orang atau $71 \%$ dan yang mendapat nilai dibawah KKM sebanyak 9 orang atau 29\%, dapat 


\section{$62 \mid$ Mawarni}

diuraikan seperti berikut diketahui bahwa 32 siswa yang mengikuti tes pada siklus I ternyata 0 siswa yang mendapat kategori sangat baik, 7 atau $22 \%$ peserta didik mendapat nilai termasuk kategori baik, 16 atau 50\% siswa mendapat nilai termasuk kategori cukup, 9 atau 28\% siswa mendapat nilai termasuk kategori kurang

Deskripsi siklus II diperoleh data hasil evaluasi yaitu, tidak ada siswa yang berada pada kategori gagal tidak ada, siswa yang berada pada kategori kurang, tidak ada siswa yang berada pada kategori cukup, tidak ada siswa yang berada pada kategori baik, 1 orang dan siswa yang berada pada kategori sangat baik sebanyak 31 orang. mencapai nilai rata-rata 87 dengan persentase ketuntasan $100 \%$. Berdasarkan nilai ketuntasan minimum pada mata pelajaran matematika dengan standar KKM 75 sehingga peneliti mengakhiri tindakan ini sampai siklus II.

Hasil analisis menunjukkan bahwa adanya perbedaan besar antara hasil Prasiklus, Siklus I dan Siklus II, Jumlah siswa yang telah menerima tingkat "sangat baik" dalam prasiklus 1 siswa, siklus I 1 siswa dan dalam siklus II 31 siswa. Pada siswa yang menerima tingkat "baik" dalam dalam prasiklus 0 siswa, siklus I 6 siswa dan dalam siklus II 1 siswa, yang menerima tingkat "cukup" dalam dalam prasiklus 16 siswa, siklus I 16 siswa dan dalam siklus II 0 siswa dan pada tingkat "kurang" dalam prasiklus 15 siswa, siklus I 9 siswa dan dalam siklus II 0 siswa.

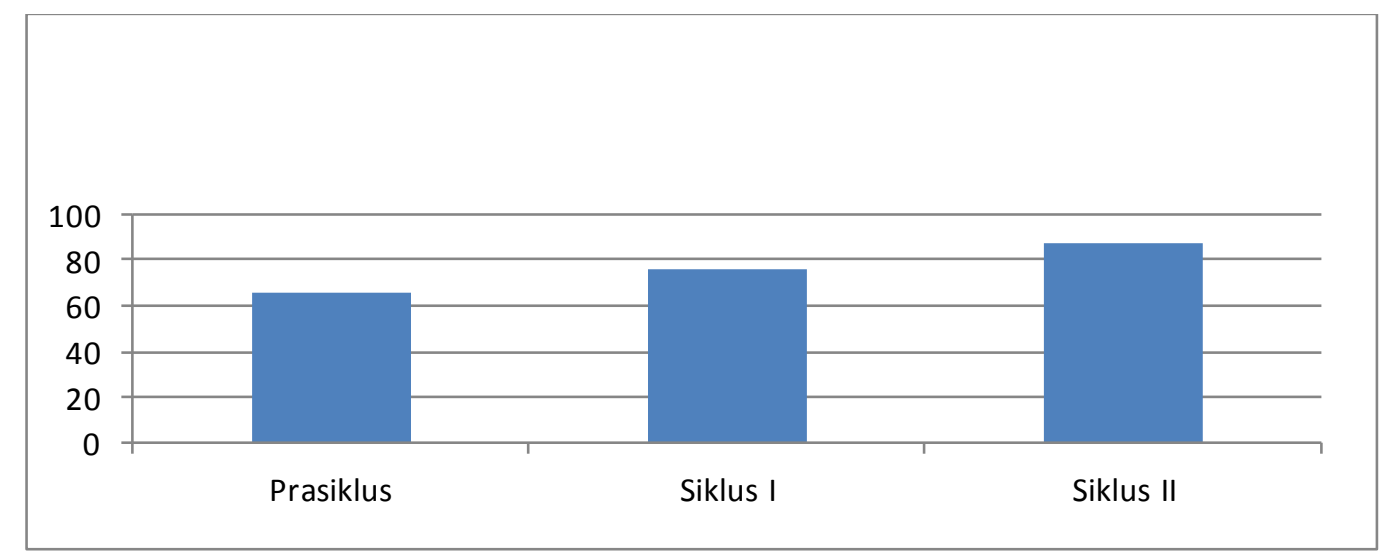

Diagram Prasiklus, Siklus I dan Siklus II

PiJIES: Pedagogik Journal of Islamic Elementary School 
Berdasarkan hasil tes prasiklus, siklus I, siklus II menunjukan bahwa dari 32 siswa yang mengikuti tes hasil evaluasi pada prasiklus nilai rata-rata yang diperoleh siswa yaitu 66. Pada siklus I diperoleh rata-rata 76 sedangkan pada Siklus II yakni 87 sehingga dapat disimpulkan bahwa berdasarkan hasil tes yang dilakukan terjadi peningkatan pemahaman pada materi yang telah disampaikan.

\section{PEMBAHASAN PENELITIAN}

Berdasarkan hasil penelitian siswa pada saat diberikan soal prasiklus, siklus I dan siklus II. Pada kegiatan prasiklus belum diterapkan media kertas origami dan diperoleh nilai rata-rata tingkat ketuntas $47 \%$, pada tahap siklus I diperoleh nilai rata-rata ketuntasan siswa mencapai 76\% sedangkan pada tahap siklus II diperoleh nilai rata-rata 100\%. Data ini menunjukkan bahwa dari tahap prasiklus hingga siklus II ditemukan perbedaan yang sangat siknifikan. Terjadinya perbedaan nilai rata-rata yang diperoleh siswa tersebut disebabkan adanya perbedaan tidakan yang diberikan guru. Adapun tindakan yang diberikan guru ialah dengan menerapkan media kertas origami pada siklus I dan siklus II namun pada tahap prasiklus belum diberikan tindakan tersebut. Berdasarkan penelitian penggunaan media origami ternyata dapat meningkatkan pemahaman materi bangun datar siswa. Media pembelajaran sangat membantu dalam meningkatkan hasil belajar siswa.

Penggunaan media alat peraga merupakan salah satu contoh media pendidikan dalam membantu proses belajar mengajar agar proses pembelajaran dapat berhasil sesuai yang diharapkan, Hal tersebut berkenaan dengan pendapat Fitrima bahwa Media memiliki tugas sebagai guru dan menjadi sumber belajar bagi peserta didiknya, dengan demikian media memiliki peran utama dalam keberhasilan pendidikan (Fitrima santri, 2016 : 121). Manfaat utama origami dalam pembelajaran matematika khususnya adalah bahwa hal itu memberikan kontribusi untuk perkembangan ide-ide matematika dan pemahaman konsep-konsep matematika.

Berdasarkan manfaat yang dapat diperoleh dari penggunaan origami sesuai dengan pendapat Pearl dalam wardani bahwa origami bukan hanya menyenangkan, tetapi menampung keanekaragaman gaya pembelajaran yang membantu anak-anak memahami matematika dan ini adalah metode inovatif untuk perkembangan pendidikan, budaya,dan kemampuan sosial (Dian Wardhani dkk., 2016: 908). Pendapat lain yang sesuai dengan pernyataan tersebut ialah Pendesainan origami berkonteks tangram dan model pembelajaran make a match membantu memahami tentang materi bangun datar dan meningkatkan kemampuan komunikasi matematis peserta 


\section{4 | Mawarni}

didik (Lisnani, 2017: 40). Indikator peningkatan pemahaman materi bangun datar siswa bukan hanya dilihat dari hasil tes yang diberikan pada setiap siklusnya. Namun, indikator lainnya dapat dilihat dari peningkatan observasi aktifitas siswa.

Terdapat beberapa aspek penilaian aktivitas siswa yaitu, aspek persiapan, aspek perhatian, aspek partisipasi, aspek pemahaman. Untuk memperoleh hasil observasi maka peneliti berperan sebagai observer yang menilai aktivitas siswa pada saat proses pembelajaran. Dari keempat aspek tersebut terdapt pula empat indikator penilaian aktifitas siswa. Indikator pada aspek persiapan yaitu kesiapan siswa sebelum memulai pembelajaran, suasana ruang kelas yang tenang, siswa tepat waktu dalam memasuki ruang kelas. Indikator pada aspek perhatian ialah siswa tidak melakukan aktivitas diluar kegiatan belajar mengajar. Indikator pada aspek partisipasi ialah siswa aktif bertanya terhadap materi yang belum dipahami, dan pada aspek pemahaman ialah siswa merespon pertanyaan yang diberikan dan membantu siswa yang belum memahami pembelajaran tersebut.

Berdasarkan lembar observasi ditemukan perbedaan aktifitas siswa pada setiap siklusnya. Meskipun telah diterapkan media pada siklus I namun perhatian siswa belum sepenuhnya terfokus pada pelajaran yang disampaikan guru hal tersebut disebabkan karena sebagian siswa kurang memahami penggunaan media tersebut seh ingga keadaan ruang belajar tidak kondusif. Berbeda dengan siklus II, siswa sudah memahami penggunaan media tersebut sehingga perhatian siswa lebih terfokus, hal ini sesuai dengan pendapat Fajar setiawan dalam tulisannya bahwa penggunaan media pemebelajaran dapat menarik perhatian siswa yang pada akhirnya dapat menumbuhkan motivasi belajar siswa, hal tersebut terlihat dari sikap siswa yang ingin melakukan percobaan membuat bangun datar dengan melipat kertas origami (Fajar Setiawan, 2017:23). Adanya motivasi yang dimiliki siswa menimbulkan kepercayaan diri siswa untuk berpartisipasi aktif dalam kegiatan pembelajaran (Rustan \& Bahru, 2018).

Hal tersebut membuktikan bahwa penggunaan media secara tepat dapat meningkatkan aktifitas siswa baik dari sisi kognitif, afektif maupun psikomotorik siswa hal tersebut sesuai dengan pernyataan Sundayana bahwa ada babarapa fungsi dari media pembelajaran dalam proses belajar mengajar, yaitu: Sebagai sarana dalam mewujudkan situasi belajar mengajar yang kondusif, pemakaian media pengajaran sebaiknya melihat tujuan pembelajaran dan bahan yang digunakan, media pelajaran seharusnya digunakan sebagaimana fungsinya, bukan digunakan sebagai hiburan semata. (Rostina Sundayana, 2013 : 8). Sehingga media kertas origami yang 
digunakan layak untuk dijadikan sebagai bahan acuan dalam pembelajaran yang lainnya khususnya pada pelajaran matematika.

\section{PENUTUP}

Berdasarkan hasil penelitian dan pembahasan maka dapat disimpulkan bahwa, Penerapan media kertas origami dalam meningkatkan pemahaman materi bangun datar di kekas VI MI Datok Sulaiman pada dasarnya mengalami peningkatan setiap siklus pada proses pembelajar an, hal ini dapat dilihat dari hasil observasi dan instrumen siswa setelah diterapkan media kertas origami nilai rata-rata yang diperoleh siswa adalah pada prasiklus ialah 66 pada siklus I 76 sedangkan pada siklus II nilai rata-rata siswa yaitu 87. Pembelajaran matematika berbasis origami merupakan pembelajaran yang menyenangkan yang disebabkan pembelajaran ini mengandung unsur kreativitas dari siswa yang dilahirkan dari kesenangan dalam belajar pengalaman melipat kertas sebelumnya. Selain itu, pembelajaran matematika berbasis origami juga dapat meningkatkan kemampuan geometri siswa dan kemampuan sosial.

\section{DAFTAR PUSTAKA}

Asnawir. 2002, Media Pembelajaran, Jakarta: Ciputat pers

Denim, Sudarwan, 2011, Pengantar Kependidikan cet. 2; Bandung: Alfabeta

Ibrahim dan nana Syaodi, 2003. Perancanaan Pengajaran, Jakarta:Rineka Cipta. Lisnani."Desain Materi Bangun Datar Menggunakan Origami Berkonteks Tangram di SD Kelas II," Suska Journal of Mathematics Education,vol.3 no. 1, 2017.

Masnur Muslic. 2012. Melaksanakan PTK Penelitian Tindakan Kelas itu Mudah Jakarta: Bumi Aksara

Moch. Islaqhuddin Baharsyah.. "Peningkatan Pemahaman Karakter Tokoh Pewayangan Bahasa Jawa Melalui Media Wayang Dua Dimensi", digital library Uin Sunan Ampel, 2014

Republik Indonesia, Undang-Undang Nomor 20 Tahun 2003 Tentang Sistem

Pendidikan Nasional, Jakarta : Direktorat Jenderal Pendidikan Islam Departemen Agama RI.

Rusman, 2011. Menejemen Kurikulum. Jakarta: Rajawali Pers

Rustan, E., \& Bahru, M. S. (2018). Penguatan Self Confidence dalam Pembelajaran Matematika melalui Metode Suggestopedia. Al-Khwarizmi: Jurnal Pendidikan Matematika Dan Ilmu Pengetahuan Alam, 6(1), 1-14.

Rustan, E., Hanifah, N., \& Kanro, B. (2018). De-radicalization in the 
66 | Mawarni

Implementation of Islamic Education Curriculum in SMA Masamba South

Sulawesi. Dinamika Ilmu, 18(2), 271-283. https://doi.org//10.21093/di.v18i2.1338

Sanjaya, Wina, 2009. Penelitian Tindakan kelas, Jakarta : Kencana Prenada Media Grup

Setiawan, Fajar.. "Upaya Meningkatkan Hasil Belajar Siswa Menggunakan Media Origami", Jurnal Bidang Pendidikan Dasar, 2017

Sudijono, Anas, 2017. Pengantar Statistik Pendidikan, Ed. 1 Cet. 18; Jakarta: PT RajaGrafindo Persada

Sundayana,Rostina. 2013. Media PembelajaranMatematika. Bandung :Alfabeta

Susanti, Liya dan Rosyidi, Abdul Haris. Pembelajaran Berbasis Origami Untuk Meningkatkan Visualisasi Spasial Dan Kemampuan Geometri Siswa SMP.

http://ejournal.unesa.ac.id/jurnal/mathedunesa/abstrak/2697/pem belajaran-berbasis-origami-untuk-meningkatkan-visualisasi-spasialdan-kemampuan-geometri-siswa-smp. Diakses 20 Desember 2017.

Syamsu S, 2017. Strategi Pembelajaran : Tinjauan Teoritis Praktis Bagi Mahasiswa Dan Praktisi Pendidikan. Cet. 1; Makassar : Nas Media Pustaka.

Vivi Utari, Dkk. " Meningkatkan Pemahaman Konsep Melalui Pendekatan PMR dalam Pokok Bahasan Proma dan Limas", Jurnal Pendidikan Matematika, vol.1 No.2

Wardhani,Dian.,dkk, "Origami Terhadap Kecerdasan Spasial Matematika Siswa,'Jurnal Pendidikan: Teori, Penelitian, dan Pengembangan,vol. 1 no. 5, Mei 2016.

Wulandari, Astri., "Pengembangan Media Papan Temple Bangun Datar Berbasis Pemecahan Masalah Matematika Siswa Kelas 4 SD” Jurnal Pigur , Vol, 01 no. 2, Agustus 2018

PiJIES: Pedagogik Journal of Islamic Elementary School 